\title{
First report of powdery mildew caused by Podosphaera sibirica on Veronicastrum sibiricum in Korea
}

\author{
In-Young Choi ${ }^{1} \cdot$ Ji-Hyun Park ${ }^{2} \cdot$ Bok-Nam Jung ${ }^{2} \cdot$ Hyeon-Dong Shin ${ }^{3} \odot$
}

Received: 5 January 2021 / Accepted: 12 February 2021 / Published online: 9 March 2021

(c) Società Italiana di Patologia Vegetale (S.I.Pa.V.) 2021

Keywords Ascospore $\cdot$ Chasmothecia $\cdot$ Medicinal plant $\cdot$ Phylogeny

During summer and autumn of 2016, dozens of Veronicastrum sibiricum (L.) Pennell growing in a flower garden in Seoul, Korea, showed a whitish mycelium on stems and leaves with a $100 \%$ disease incidence. Conidiophores with immature catenate conidia were hyaline, upright, and $90-200 \times 10-12 \mu \mathrm{m}$. Conidia were ellipsoid-ovoid to doliform, 32-40 $\times 18-22 \mu \mathrm{m}$, and contained conspicuous fibrosin bodies. Dark brown chasmothecia were scattered to gregarious, spherical, 80-106 $\mu \mathrm{m}$ in diameter, and contained a single ascus. Appendages were few, mycelioid, and 5-9 $\mu \mathrm{m}$ wide. Asci with a terminal oculus of 10-16 $\mu \mathrm{m}$ wide were sessile, 8-spored, and 60-90×45-60 $\mu \mathrm{m}$. Ascospores were colorless, ellipsoidal, and 16-26×12-16 $\mu \mathrm{m}$. These features were consistent with those of Podosphaera sibirica (U. Braun) U. Braun \& Takam. (Braun and Cook 2012). For further confirmation, rDNA was extracted from KUS-F29533 (Korea University Herbarium). PCR products were amplified using the primer pair ITS1F/PM6 for internal transcribed spacer (ITS), and PM3/TW14 for the large subunit (LSU) of the rDNA. The resulting sequences were registered to GenBank (Accession Nos. MW431328 for ITS, MW431327 for LSU). Blast'n search using these sequences showed $99.78 \%$ (461/462 bp) for ITS and 99.89\% (945/946 bp) for LSU with $P$. sibirica (AB026144 and AB462761, respectively). P. sibirica has been recorded in Japan and the Far East of Russia (Farr and Rossman 2021). Therefore, this is the first report

Hyeon-Dong Shin

hdshin@korea.ac.kr

1 Department of Agricultural Biology, Department of Agricultural Convergence Technology, Jeonbuk National University, Jeonju 54896, Korea

2 Division of Forest Insect Pests and Diseases, National Institute of Forest Science, Seoul 02455, Korea

3 Division of Environmental Science and Ecological Engineering, Korea University, Seoul 02841, Korea of $P$. sibirica on $V$. sibiricum in Korea. $V$. sibiricum has long been used as a medicinal plant in Asia and is also becoming popular as an ornamental garden plant in Korea (Kim and Kim 2018). Occurrence of powdery mildew on V. sibiricum poses a potential threat to the health and beauty of this plant.

Acknowledgements This work was supported by Korea Institute of Planning and Evaluation for Technology in Food, Agriculture and Forestry (IPET) through Crop Viruses and Pests Response Industry Technology Development Program, funded by Ministry of Agriculture, Food and Rural Affairs (MAFRA) (Project No. 320043-05).

\section{Declarations}

Informed consent The manuscript is new and not being considered elsewhere. All authors have approved the submission of this manuscript.

Research involving human participants and/or animals The authors declare that no human participants and animals were involved in this study.

Conflict of interest The authors have no conflict of interest to declare.

\section{References}

Braun U, Cook RTA (2012) Taxonomic manual of the Erysiphales (Powdery Mildews), CBS Biodiversity Series No. 11. CBS, Utrecht, The Netherlands

Farr DF, Rossman AY (2021) Fungal databases, syst. Microbiol. Lab., Online publication. ARS, USDA, Mycol

Kim MI, Kim CY (2018) Four new acylated iridoid glycosides from the aerial part of Veronicastrum sibiricum and their antioxidant responses element-inducing activity. Chem Biodivers 15:e1700447

Publisher's Note Springer Nature remains neutral with regard to jurisdictional claims in published maps and institutional affiliations. 